\title{
The effectiveness of STEM-based PjBL on student's critical thinking skills and collaborative attitude
}

\author{
Vera Rosalina Bulu' ${ }^{1}$, Femberianus Tanggur ${ }^{1}$ \\ ${ }^{1}$ Citra Bangsa University, Indonesia \\ $\triangle$ veraros0451@gmail.com *
}

Article Information

Submitted May 05, 2021

Revised May 20, 2021

Accepted May 24, 2021

\section{Keywords}

Critical Thinking;

Collaboration;

PjBL;

STEM.

\section{Abstract}

PjBL and STEM learning models can overcome the lack of critical thinking skills and collaboration. Those learning models involve $4 \mathrm{C}$ that support students' critical thinking skills and collaboration. This study aimed to identify the effectiveness of STEM-based PJBL models on students' critical thinking skills and collaborative attitudes. This study was quantitative research with a descriptive method. The data had been collected using a critical thinking skills test, collaborative attitude questionnaires, and learning observation guidelines. Before performing data analysis, the researchers performed prerequisite tests consisting of the normality test, homogeneity test, variance-covariance matrix homogeneity test, N-Gain test, and effectiveness test. The basic assumption test results showed that the MANOVA test could be performed. The MANOVA test results revealed that the STEM-based PjBL learning model effectively improved students' critical thinking skills and collaborative attitudes.

\section{INTRODUCTION}

The educational development in the 4.0 industrial era demands learners' perception of learning quality to be transformed. Learning is not solely to get scores but also to expand and transform knowledge into other disciplines and solve daily problems. Tertiary education plays a vital role in realizing these goals by implementing a curriculum that can improve and develop learners' cognitive, skill, and affective domains. The skills and attitude are expected to foster a high learning accomplishment that cultivates higher-order thinking skills (HOTS) that cover Communication, Collaboration, Critical thinking, Creative thinking, Computational logic, Compassion, and Civic responsibility (Penyusun, 2020). Besides, students are expected to have a collaborative attitude, social awareness, and forethought of community and environment.

Critical thinking skill is not obtained through physical growth, but continuous practice (Fakhriyah, 2014). The same rule applies to the collaborative attitude, which must be practiced within a group's communication repeatedly. In mathematical learning, learners must have critical thinking skills since it helps them analyze a problem, give a critical response, and find the solution when they deal with the problem (Dywan \& Airlanda, 2020; Afifah, Wahyudi, 2019). Moreover, it also increases intelligence and creativity in solving problems (Nurrohmi et al., 2017). Similarly, positive collaboration helps individuals or groups to achieve goals and shape learners to be tolerant, open-minded toward others' ideas, attitudes, and behaviors (Awaliyah et al., 2016; Dani et al., 2020; Pratiwi et al., 2018).

On the contrary, the learning recently lacks the emphasis on training students' criticality due to the use of inadequate approach, model, method, or learning materials. Hayati et al. also proposed that students are not well trained to think critically since the teachers apply unsuitable learning models and methods. Students' collaborative attitude also needs to be 
integrated into learning since the learning process tends to be monotonous and teachercentered, with a rare opportunity for students to work in groups.

There are various applicable ideas to improve critical thinking skills and a collaborative attitude. One of the applicable models is the STEM-based PjBL model, which can increase students critical thinking skills (Astuti et al., 2019; Afifah, Wahyudi, 2019; Fitri et al., 2018; Guo et al., 2020; Tipani et al., 2019). This theory is also supported by Almulla (Almulla, 2020; Ralph, 2016; Trisdiono et al., 2019), who states that the STEM-based PjBL model is a collaborative learning model due to its characteristic that demands students' active learning in groups and information sharing to facilitate their insight in critical thinking. Dywan and Airlanda (Dywan \& Airlanda, 2020) also propose that the STEM-based PjBL model activates a process that enabled students to participate, solve problems, and inquire about new different experiences so they can reflect their ideas critically.

The description revealed that previous studies mainly examined the effectiveness of STEM-based PjBL on students' critical thinking skills. Compared to those research, this study questioned its effectiveness on students' collaborative attitude as it was perceived essential to maximize the quality of a learning community. This study was conducted in tertiary education, considering it was a medium to produce qualified graduates for the working world, especially elementary teachers who will educate primary schools.

STEM-based PjBL model can also develop an excellent collaborative attitude among students. This model allows them to actively participate in groups, ask questions, discuss encountered problems, state their ideas, and design products together. Erlinawati (Erlinawati et al., 2019; Maulana, 2020) confirms that the PjBL model involved 4Cs consisting of critical thinking, communication, collaboration, and creativity. Moreover, the STEM-based PjBL model is pertinent in mathematics and science learning (Toto, 2019). Based on the description, the researchers intended to identify the effectiveness of the STEM-based PjBL model on students' critical thinking skills and collaborative attitude in a mathematics course.

\section{METHODS}

This study was conducted in the first semester of the 2020/2021 academic year in PGSD (Primary School Teacher Education Program) of Citra Bangsa University, Kupang. This study was conducted using a quasi-experimental design. The control group of this design was a nonrandomized extraneous variable.

\begin{tabular}{|llll|}
\hline Experimental Group & $\mathrm{O}_{1}$ & $\mathrm{X}$ & $\mathrm{O}_{2}$ \\
Control Group & $\mathrm{O}_{3}$ & & $\mathrm{O}_{4}$ \\
\hline
\end{tabular}

Figure 1. Non-Equivalent Control Group Design

Details :

$\mathrm{X}$ : Treatment

$\mathrm{O}_{1}$ : Pretest on Experimental Group

$\mathrm{O}_{2}$ : Posttest on Experimental Group

$\mathrm{O}_{3}$ : Pretest on Control Group

$\mathrm{O}_{4}$ : Posttest on Control Group

Moreover, this study employed independent and dependent variables. The independent variable $(\mathrm{X})$ was the STEM-based PjBL model, and the dependent variable (Y) consisted of 
critical thinking skills $\left(\mathrm{Y}_{1}\right)$ and collaborative attitude $\left(\mathrm{Y}_{2}\right)$. The relationship between $\mathrm{X}$ and $\mathrm{Y}$ variables is portrayed in the following figure.

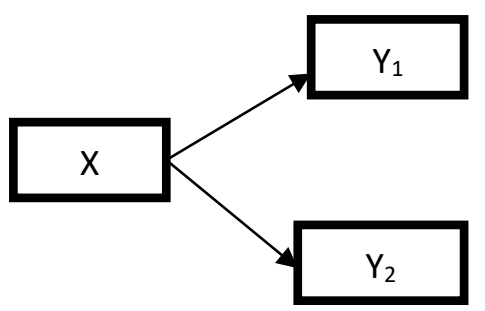

Figure 2. Relation between $\mathrm{X}$ and $\mathrm{Y}$ Variables

Details:

$\mathrm{X}=$ STEM-based PjBL model

$\mathrm{Y} 1=$ Critical thinking skill

Y2 = Collaborative attitude

The population of this study consisted of fifty-five 3rd-semester students of PGSD (Primary School Teacher Education Program) of Citra Bangsa University, Kupang. They were divided into two classes, namely III A and III B. The samples of this study were 55 students from 3rd-semester students who had been divided into two classes. This type of sample is termed a population sample since the sample size is similar to the population. The samples were selected using purposive sampling based on specific considerations of their critical thinking skills and collaboration attitude. The samples were classified into control group (IIIA) and experimental group (III B).

Test and non-test instruments were utilized to collect the data. The non-test techniques consisted of a questionnaire to measure students' collaborative attitude and observation to examine the completion of $\mathrm{PjBL}$ in mathematic learning. On the other hand, the test technique was composed of a description test to evaluate their critical thinking skills. The critical thinking test instrument had been thoroughly examined using validity test, reliability test, difficulty level test, an equivalent form. Likert scale was applied in students' active learning instrument with four categories as presented in table 1.

Table 1. The Students' Active Learning Instrument

\begin{tabular}{ll}
\hline Scale & Categories \\
4 & Strongly Agree (SA) \\
3 & Agree (A) \\
2 & Disagree (D) \\
1 & Strongly Disagree (SD) \\
\hline
\end{tabular}

Expert's validity test was used for this instrument. An observation checklist was used to measure the completion of the STEM-based PjBL model in mathematic learning. The checklist also used the Likert scale, as presented in table 2.

Table 2. Observation Checklist

\begin{tabular}{ll}
\hline Scale & Categories \\
5 & Excellent \\
4 & High \\
3 & Moderate \\
2 & Low \\
1 & Poor \\
\hline
\end{tabular}


The prerequisite tests of normality test, variance homogeneity test, and variancecovariance matrix test were used in data analysis. The following tests were the $\mathrm{N}$-gain test and effectiveness test to know whether students' critical thinking skills and collaborative attitudes increased or not. Also, the hypothesis was tested using multivariate analysis of variance (MANOVA) using SPSS 16.0.

\section{RESULTS AND DISCUSSION}

\section{Result}

Table 3. The Pretest Result

\begin{tabular}{lllll}
\hline \multirow{2}{*}{ Score } & \multicolumn{2}{c}{ Critical Thinking Skill } & \multicolumn{2}{c}{ Collaboration } \\
& Experimental & Control Group & Experimental & Control \\
& Group & & Group & Group \\
Highest & 75 & 70 & 40 & 65 \\
Lowest & 60 & 60 & 75 & 45 \\
Mean & 65,50 & 63,20 & 61,16 & 54,6 \\
\hline
\end{tabular}

The result showed that the experimental group's mean score was higher than the control group. The posttest results are presented in Table 4.

Table 4. The Posttest Results

\begin{tabular}{lllll}
\hline \multirow{3}{*}{ Score } & \multicolumn{2}{c}{ Critical Thinking Skill } & \multicolumn{2}{c}{ Collaborative Attitude } \\
& Experimental & Control & Experimental & Control Group \\
& Group & Group & Group & \\
Highest & 90 & 80 & 95 & 90 \\
Lowest & 70 & 65 & 75 & 70 \\
Mean & 82,67 & 71,40 & 83,16 & 80,60 \\
\hline
\end{tabular}

Table 4 shows that the experimental group's mean score was higher than the control group. In collaborative attitude, the experimental group obtained 83,16 while the control group obtained 80,60 . The results indicated that the experimental group had a higher posttest mean score than the control group regarding collaborative attitude.

A prerequisite test consisted of normality, and homogeneity tests were performed after the pretest and posttest. These tests are needed to see whether the data were normally distributed and homogeneous. The result of the normality test is presented in table 5.

Table 5. The Results of Normality Test

\begin{tabular}{ccccccc}
\hline $\begin{array}{c}\text { Kolmogorov } \\
\text { Smirnov test }\end{array}$ & \multicolumn{2}{c}{ Critical Thinking Skill } & \multicolumn{2}{c}{ Collaborative Attitude } & \multirow{2}{*}{ Result } & Interpretation \\
characteristic & Experimental & Control & Experimental & Control & & \\
Sig & 0.08 & 0.08 & 0.06 & 0,11 & Sig $>\alpha$ & Normally \\
A & 0,05 & 0,05 & 0,05 & 0,05 & Distributed \\
\hline
\end{tabular}

Table 5 confirms that the result of the experimental group's collaborative attitude was $0,06>$ 0,05 , and the control group was $0,11>0.05$, which indicated that the data were normally distributed. The other prerequisite test was the homogeneity test to assess the inter-item consistency of data variance. The results can be seen in Table 6. 
Table 6. Variance Homogeneity

\begin{tabular}{lcccc}
\hline & F & df1 & df2 & Sig. \\
Critical Thinking Skill & .325 & 1 & 53 & .571 \\
Collaborative Attitude & .248 & 1 & 53 & .621 \\
\hline
\end{tabular}

Based on the result in Table 6, the significance level of students' critical thinking skill was $0,571>0,05$ and collaborative attitude was $0,621>0,05$. Then, a variance-covariance matrix homogeneity measure was conducted.

This measure is a basic assumption test of the MANOVA test. Box's M statistical test was employed using the IBM SPSS Statistics 16 application to examine variance-covariance matrix homogeneity measure. The result is shown in table 7.

Table 7. Variance-Covariance Matrix Homogeneity Measure

\begin{tabular}{cc}
\hline Box's M & 1.121 \\
F & .358 \\
df1 & 3 \\
df2 & 3.824 \\
Sig. & .783 \\
\hline
\end{tabular}

Table 7 indicates that the Box's M score was 1,121 with a significance level of 0,783. Based on the criterion that if $\operatorname{sig}>\alpha$, then $\mathrm{H}_{0}$ is accepted. Since sig $>\alpha$ or $0,783>0,05$, it can be concluded that $\mathrm{H}_{0}$ is accepted, which means that the two dependent variables (critical thinking skill and collaborative attitude) had a similar variance-covariance matrix to the independent variable (STEM-based PjBL model).

Students' critical thinking skills and collaborative attitudes were analyzed using N-gain and effectiveness tests. The N-gain was performed to check students' critical thinking skill improvement.

Table 8. The N-Gain Test Results on Students' Critical Thinking Skills

\begin{tabular}{cccccc}
\hline Group & $\mathrm{N}$ & Minimum & Maximum Score & N-Gain $(\%)$ & Category \\
Experimental & 30 & 28,57 & 90,91 & 59,85 & Quite Effective \\
Control & 25 & 22,22 & 60,00 & 40,13 & Not Effective \\
\hline
\end{tabular}

Table 8 points out that the PjBL model was adequately effective in increasing students' critical thinking skills.

The effectiveness test can be inferred from Effect size to demonstrate how far an independent variable (STEM-based PjBL model) influence the dependent variable (students' critical thinking skill). The result of the effectiveness test is shown in Table 9.

Table 9. The Effect Size Test results on Students' Critical Thinking Skills

\begin{tabular}{cccc}
\hline $\begin{array}{c}\text { Experimental Group's } \\
\text { Standard Deviation }\end{array}$ & $\begin{array}{c}\text { Control Group's Standard } \\
\text { Deviation }\end{array}$ & Effect Size & Category \\
\hline 1,78 & 1,51 & 1,45 & High \\
\hline
\end{tabular}

Based on Table 9, the experimental group's standard deviation was 1,78, and the control group's standard deviation was 1,51. The effect size test result was 1,45, which was categorized as high.

$\mathrm{N}$-Gain and effectiveness tests were also done to determine students' collaborative attitudes. The results are presented in Table 10 and Table 11 . 
Table 10. The N-Gain Test Results on Students' Collaborative Attitude

\begin{tabular}{cccccc}
\hline Group & $\mathrm{N}$ & $\begin{array}{c}\text { Minimum } \\
\text { Score }\end{array}$ & $\begin{array}{c}\text { Maximum } \\
\text { Score }\end{array}$ & N-Gain(\%) & Category \\
Experimental & 30 & 14,29 & 87,50 & 56,44 & Quite Effective \\
Control & 25 & 0,00 & 55,56 & 31,30 & Not Effective \\
\hline
\end{tabular}

Table 10 displays that students' collaborative attitude N-Gain score in the experimental group was 0,56 , whereas the control group scored 0,31 . The results indicated that the PjBL model was adequately effective in improving students' collaborative attitudes.

After the N-Gain test, the collaborative attitude effectiveness test was performed. This test can be inferred from the Effect Size to demonstrate how far an independent variable (STEM-based PjBL model) influences the dependent variable (students' collaborative attitude). The result is presented in Table 11 .

Table 11. The Effect Size Results on Students' Collaborative Attitude

\begin{tabular}{cccc}
\hline Experimental Group's & Control Group's & Effect & Category \\
Standard Deviation & Standard Deviation & Size & High \\
1,76 & 1,25 & 1,29 & \\
\hline
\end{tabular}

As presented in table 11, the experimental group's standard deviation was 1,76, and the control group's standard deviation was 1,25. Furthermore, the effect size test result was 1,29, which was categorized as high. The hypothesis was tested using the Multivariate test and Between Subjects-Effect test. The result of the multivariate test is shown in table 12.

Table 12. Multivariate Test

\begin{tabular}{lll}
\hline & Effect & Sig \\
& Pillai's Trace & .000 \\
Treatment & Wilks' Lambda & .000 \\
& Hotelling's Trace & .000 \\
& Roy's Largest & .000 \\
& Root & \\
\hline
\end{tabular}

The multivariate test reveals the mean comparison assessment of critical thinking skill and collaborative attitude components on the treatment components (experimental and control) with Pillai's Trace, Wilks' Lambda, Hotelling's Trace, Roy's Largest Root statistical tests. Based on the result, effective treatment was performed by Pillai's Trace, Wilks' Lambda, Hotelling's Trace, and Roy's Largest Root procedure. All gain score was 0.000, in which 0.000 was lower than 0.05 , so $\mathrm{H}_{0}$ was rejected and $\mathrm{H}_{1}$ was accepted. Therefore, the independent variable (STEM-based PjBL) poses differences in the two dependent variables (critical thinking and collaborative attitudes). The result of Between Subjects Effect test is shown in table 13.

Table 13. Between Subjects Effect Test

\begin{tabular}{lllll}
\hline Source & $\begin{array}{l}\text { Dependent Variable } \\
\text { Intercept }\end{array}$ & F & Sig. \\
& $\begin{array}{l}\text { Students' Critical Thinking } \\
\text { Skill }\end{array}$ & &, 000 \\
& $\begin{array}{l}\text { Students' } \\
\text { Attitude }\end{array}$ & Collaborative & 82,83 &, 000 \\
& & & \\
\hline
\end{tabular}

Table 13 shows that the $F_{\text {observed }}$ and $F_{\text {critical }}$ of students' critical thinking skills were 17,82 and 4,02. Therefore, $F_{\text {observed }}$ was higher than $F_{\text {critical. }}$ The result shows that the mean of the $Y_{1}$ variable (students' critical thinking skill) demonstrated a difference toward $\mathrm{X}$ variable 
(Treatment). Besides, the $\mathrm{F}_{\text {observed }}$ of students' collaborative attitude was 82,83 , and the $\mathrm{F}_{\text {critical }}$ was 4,02. Therefore, $F_{\text {observed }}$ was higher than $F_{\text {critical }}$. It means that the mean of the $\mathrm{Y}_{2}$ variable (students' collaboration attitude) demonstrated a difference toward X (Treatment).

\section{Discussion}

The research treatment began by administering pretest to the control and experimental groups to recognize students' prior knowledge. The pretest result implied that students in the experimental group had higher critical thinking skills and a collaborative attitude than students in the control group.

Then, the STEM-based PjBL model was implemented in the experimental group, while the control group was treated using the conventional method through lectures and discussion. Posttests were given when the treatment ended. It appeared that the experimental group achieved a higher score than the control group. The pretest and posttest results were tested using the N-Gain test to examine the improvement in critical thinking skills and collaborative attitude. The result of the N-Gain test demonstrated that both traits improved after the treatments.

The hypothesis testing using MANOVA showed that the STEM-based PjBL model effectively improved the critical thinking skill and collaborative attitude of the 3rd-semester PGSD students of Citra Bangsa University. The STEM-based PjBL model is a collaborative learning model that encourages students to design a project plan, discuss the planned project in a group, and execute the project. These enforce students to sharpen their critical-thinking skills, foster their creativity in designing and producing the project, cultivate a collaborative attitude in the group, collaborate ideas for project execution, and encourage learning motivation due to a positive learning environment. Specifically, students are trained to be independent in groups during the discovery stage to develop their obtained knowledge and conduct research that benefits their critical thinking and collaborative attitude training. This finding is in line with (Astuti et al., 2019; Afifah, Wahyudi, 2019; Guo et al., 2020; Tipani et al., 2019), who states that implementing STEM-based PjBL model can improve critical thinking skill. It is further suggested that students are conditioned to observe problems, investigate problems, gather information regarding problem-solving, and solve the problems to think critically. Besides, students in groups who solve problems will be guided to be collaborative.

Moreover, Afifah and Wahyudi (Afifah, Wahyudi, 2019) suggest that the activities done in learning are oriented to ensure students' active participation to stimulate their critical thinking skills. Additionally, Andrew (Andrew Mamahit et al., 2020) declared that the PjBL model improves students' critical thinking and sense of responsibility to solve the problem and collaborate because they are required to solve the problems in the group. This notion is supported by Astuti (Astuti et al., 2019). They claim that the PjBL model can create an exciting learning experience for students aside from its collaborative nature.

There are several advantages of $\mathrm{PjBL}$ found in this study. First, students find it easier to understand concepts since they are related to real-life experiences. Second, students become more creative and critical as they are guided to plan and create a project. Third, students are tutored to work in a group by collaborating ideas needed for a project. These findings are supported by Kristiani (Kristiani et al., 2017). They recommend that integrating several disciplines (mathematics with science, technology, and engineering) in the STEM-based PjBL 
model leads students to perceive that every discipline is strongly related to other fields. Astuti (Astuti et al., 2019) states that Project-Based Learning and STEM (Science, Technology, Engineering, and Mathematics) possess traits to enable students to grasp concepts through creating products. In STEM learning, design and redesign (engineering design process) occur so students can produce their optimal results. (Maulana, 2020) also suggests that the STEMbased PjBL model allows the students to acquire intellectual intelligence and shape students' curiosity, independence, and cooperation. Further, (Zubaidah, 2016) declares that critical thinking skills and a collaborative attitude enable people to obtain a higher score and develop a collaborative working environment.

Besides, this study reveals a new finding that is different from other findings in previous studies. It was found that the students can learn to make a fair decision in a group and plan in the group by collaborating ideas. It was pretty tricky since they used to plan and decide by themselves because of their learning habits. However, the STEM-based PjBL model requires them to do things in a group.

The STEM-based PjBL model also has disadvantages. It takes time to be applied in learning. Besides, the STEM-based PjBL model needs to be adapted to course materials. Similarly, Astuti (Astuti et al., 2019) mentions that STEM learning needs to be adapted to materials and circumstances since the PjBL requires time to solve problems and create products. It also does not suitable for students who are not hard workers and lacks skills. Furthermore, by discussing each stage of projects and the results, the students can be familiar with their ideas and arguments in front of their peers confidently and appropriately.

\section{CONCLUSIONS}

It can be concluded that the STEM-based PjBL model is effective in improving students' critical thinking skills and collaborative attitude during online learning practiced by the 3rdsemester PGSD students of Citra Bangsa University, Kupang. Based on the result of the study, it is recommended that the STEM-based PjBL model be applied to other courses to improve students' critical thinking skills and collaborative attitude.

\section{AUTHOR CONTRIBUTIONS STATEMENT}

VRB as the principal investigator and correspondence in this article. data collection and instrument design assisted by FT.

\section{REFERENCES}

Afifah, E. P., Wahyudi, Y. S. (2019). Efektivitas problem based learning dan problem solving terhadap kemampuan berpikir kritis siswa kelas V dalam pembelajaran. Journal of Mathematics Education, Science and Technology, 4(1), 95-107.

Almulla, M. A. (2020). The effectiveness of the project-based learning (PjBL) approach as a way to engage students in learning. SAGE Open, 10(3), 1-15.

Andrew Mamahit, J., Corebima Aloysius, D., Suwono, H., \& Artikel Abstrak, I. (2020). Efektivitas model project-based learning terintegrasi STEM (PjBL-STEM) terhadap keterampilan berpikir kreatif siswa kelas X. Jurnal Pendidikan: Teori, Penelitian, Dan Pengembangan, 5(9), 1284-1289. 
Astuti, I. D., Toto, T., \& Yulisma, L. (2019). Model project based learning (PjBL) terintegrasi STEM untuk meningkatkan penguasaan konsep dan aktivitas belajar siswa. Quagga: Jurnal Pendidikan Dan Biologi, 11(2), 93-98.

Awaliyah, C.R., Firman,H., Hasanah,L. (2016). The implementation of project-based learning (PjBL) to enchance junior high school student's concept mastery learning and creativity in ecosyst.

Dani, G., Rahayu, S., \& Fauzi, M. R. (2020). The effect of the project-based learning model on students' resilience during the pandemic COVID-19. Jurnal Pendidikan Indonesia, 9(4), 711-718.

Dywan, A. A., \& Airlanda, G. S. (2020). Efektivitas model pembelajaran project based learning berbasis STEM dan tidak berbasis STEM terhadap kemampuan berpikir kritis siswa. Jurnal Basicedu, 4(2), 344-354.

Erlinawati, C. E., Bektiarso, S., \& Maryani. (2019). Model pembelajaran project based learning berbasis STEM pada seminar nasional pendidikan fisika 2019. Seminar Nasional Pendidikan Fisika 2019, 4(1), 1-4.

Fakhriyah, F. (2014). Penerapan problem based learning dalam upaya mengembangkan kemampuan berpikir kritis mahasiswa. Jurnal Pendidikan IPA Indonesia, 3(1), 95-101.

Fitri, H., Dasna, I. W., \& Suharjo, S. (2018). Pengaruh model project based learning (PjBL) terhadap kemampuan berpikir tingkat tinggi ditinjau dari motivasi berprestasi siswa kelas IV sekolah dasar. Brilliant: Jurnal Riset Dan Konseptual, 3(2), 201-212.

Guo, P., Saab, N., Post, L. S., \& Admiraal, W. (2020). A review of project-based learning in higher education: Student outcomes and measures. International Journal of Educational Research, 102, 101586.

Kristiani, K. D., Mayasari, T., \& Kurniadi, E. (2017). Pengaruh pembelajaran STEM-PjBL terhadap keterampilan berpikir kreatif. Prosiding SNPF (Seminar Nasional pendidikan fisika), 21, 266-274.

Maulana, M. (2020). Penerapan model project based learning berbasis STEM pada pembelajaran fisika siapkan kemandirian belajar peserta didik. Jurnal Teknodik, 2, 3950 .

Nurrohmi, Y., Utaya, S., \& Utomo, D. H. (2017). Pengaruh model pembelajaran discovery learning terhadap kemampuan berpikir kritis. Jurnal Pendidikan, 2(1), 1308-1314.

Penyusun, T. (2020). Panduan penyusunan kurikulum pendidikan tinggi.

Pratiwi, I. A., Ardianti, S. D., \& Kanzunnudin, M. (2018). Peningkatan kemampuan kerjasama melalui model project based learning (PjBL) berbantuan metode edutainment pada mata pelajaran ilmu pengetahuan sosial. Refleksi Edukatika: Jurnal Ilmiah Kependidikan, 8(2), 177-182.

Ralph, R. A. (2016). Post secondary project-based learning in science, technology, engineering and mathematics. Journal of Technology and Science Education, 6(1), 2635 . 
Tipani, A., Toto, T., \& Yulisma, L. (2019). Implementasi model PjBL berbasis STEM untuk meningkatkan penguasaan konsep dan kemampuan berpikir analitis siswa. BIO EDUCATIO : (The Journal of Science and Biology Education), 4(2), 70-76.

Toto, T. (2019). STEM-based science learning design in the 2013 curriculum. Journal Of Physics: Conference Series, 1233, 1-7.

Trisdiono, H., Siswandari, S., Suryani, N., \& Joyoatmojo, S. (2019). Multidisciplinary integrated project-based learning to improve critical thinking skills and collaboration. International Journal of Learning, Teaching and Educational Research, 18(1), 16-30.

Zubaidah, S. (2016). Keterampilan abad ke-21: Keterampilan yang diajarkan melalui pembelajaran universitas negeri Malang. In Seminar Nasional Pendidikan, 2(2), 1-17. 